\title{
Variation in and among early life history traits of laboratory-reared winter flounder Pseudopleuronectes americanus*
}

\author{
R. Christopher Chambers ${ }^{1}$, William C. Leggett ${ }^{1}$, Joseph A. Brown ${ }^{2}$ \\ ${ }^{1}$ Department of Biology, McGill University, 1205 Ave. Dr. Penfield, Montreal, Québec, Canada H3A 1B1 \\ ${ }^{2}$ Marine Sciences Research Laboratory, Memorial University of Newioundland, St John's, Newioundland, Canada A1C 5S7
}

\begin{abstract}
We analyzed variation in and among early life history traits of laboratory-reared winter flounder Pseudopleuronectes americanus. We measured lengths and ages at hatching and metamorphosis, lengths at $2 \mathrm{wk}$ intervals through the larval period and into the first $3 \mathrm{wk}$ of the juvenile period, and after $23 \mathrm{wk}$ of juvenile life. Variation in traits was quantified and compared by the coefficient of variation $(\mathrm{CV}=\mathrm{SD} / \mathrm{mean})$. CVs for lengths-at-ages increased from hatching $(0.03)$ to an asymptotic value of $\simeq 10 \%$ by 2 to $4 \mathrm{wk}$ after first feeding. There were 2 peaks in variation in lengths-at-age during the early life history; one at Week 4 (the approximate midpoint of the larval period) and another Week 10 (during the latter portion of the metamorphic window and early juvenile life). These may reflect commensurate changes observed in growth rates. Variation in length at hatching and metamorphosis was relatively low $(3.0$ and $5.3 \%$, respectively), and less than variation in age. Lengths-at-transitions were also less variable than lengths at fixed ages during the larval and juvenile periods. These findings imply a target size for life period transitions. Length and age at metamorphosis were positively correlated, as were sequential average lengths calculated from fortnightly measures. Length and age at metamorphosis, and growth and developmental rates through the entire larval period, were positively correlated when calculated from the bivariate measure of individuals. The pattern of variation in and correlations among early life history traits established in the larval period appears to propagate through metamorphosis and into early juvenile life. The population consequences of these associations, and their potential use in analyzing the results of early life history studies, are discussed.
\end{abstract}

\section{INTRODUCTION}

The motivation for many ecological studies of the early life history of marine fishes comes from 2 observations. First, the highest mortality in marine fishes occurs early in the life cycle. This mortality is concentrated in the embryonic and larval periods (Hjort 1914, Gulland 1965, McGurk 1986). Second, small changes in instantaneous mortality rates during these periods, or in the duration of the periods over which these rates apply, could dramatically alter the abundance of fish entering the juvenile and adult population (Murphy 1961, Lasker 1964, Smith 1985, Chambers \& Leggett 1987).

\footnotetext{
- Contribution to the programs of GIROQ (Groupe interuniversitaire de recherches océanographiques du Québecl and the Huntsman Marine Laboratory
}

Developmental and growth rates in the early life history are crucial parameters in fish population dynamics. They determine the duration of residence in and the size at transition between life periods (embryonic, larval, or juvenile), as well as the size of a fish at any age. It is widely believed that the magnitude and sources of mortality vary with the life period and size of the fish (Ware 1975, Hunter 1981, Hewitt et al. 1985, Smith 1985, Folkvord \& Hunter 1986, Leggett 1986, Purcell et al. 1987). The average values of several early life history traits that are determined by developmental and growth rates, such as age and size at hatching and size at metamorphosis, have been extensively reported for laboratory and natural populations of a number of marine fishes (Fahay 1983). The variation about these averages is seldom reported and is only rarely analyzed or interpreted in studies of marine fishes (Chambers \& Leggett 1987). We consider this to be a major gap in our 
present knowledge of marine fishes, given that for any trait-dependent ecological process (e.g. size-specific predation, period-specific mortality), it is the expressed variation in that trait upon which selection operates.

In this paper we contribute to a resolution of this shortcoming by analyzing among-individual variation in development and growth during the early life history of fishes. We employed winter flounder Pseudopleuronectes americanus in our studies because we consider it to be an excellent experimental model for other marine fishes that undergo an ecological transition from the pelagic to demersal habitat coincidental with the morphological metamorphosis between the larval and juvenile periods. Flatfish are ideal for this purpose because their dramatic metamorphosis, including migration of one eye across their midline, is easily and accurately scored.

We address 4 questions that are fundamental to our understanding of ontogeny in the early life history of marine fishes and of the role it may play in population dynamics: (1) Does variation in fish size change in a predictable way during the early life history? (2) Do developmental traits and growth traits display characteristic patterns of variation that would justify viewing them as trait suites? (3) Are developmental traits more or less variable than growth traits? (4) What is the direction and magnitude of correlations among early life history traits?

We chose a laboratory approach so that variation could be assessed under constant conditions. We view this study as a baseline for analysis of early life history traits of marine fishes to which subsequent work, using different species and environments, can be compared.

\section{METHODS}

Winter flounder is a pleuronectid flatfish found in shallow coastal waters from Georgia, USA, to Newfoundland and Labrador, Canada. Its early life history is well studied in both laboratory (Laurence 1975, 1977 , Williams 1975, Rogers 1976, Buckley 1982, Cetta \& Cappuzo 1982, Chambers \& Leggett 1987) and field settings (Pearcy 1962a, b, c, Laurence et al. 1979, Crawford \& Carey 1985). A synopsis of its ecology and bionomics is provide by Klein-McPhee (1978).

Adult winter flounder were collected by gill netting and SCUBA diving in late May 1986 at Bryants Cove, Newfoundland $\left(47^{\circ} 40.6^{\prime} \mathrm{N}, 53^{\circ} 11.4^{\prime} \mathrm{W}\right)$. Males and females were held separately at an on-site laboratory in flow-through tanks supplied with seawater pumped directly from the cove. Water temperatures in the holding tanks averaged ca $6^{\circ} \mathrm{C}$ and the adults ripened within $3 \mathrm{wk}$.

Each of 7 males was crossed with 2 individual fema- les to create 14 full-sibling families. Details of the fertilization technique are given in Chambers \& Leggett (1987). Fertilized eggs were kept at $5^{\circ} \mathrm{C}$ throughout the incubation period. Water in the incubation containers was changed every second day until hatching. An antibiotic treatment of streptomycin (final concentration $0.02 \mathrm{mg} \mathrm{ml}^{-1}$ ) and penicillin $\mathrm{G}$ (final concentration $25 \mathrm{IU} \mathrm{ml}^{-1}$ ) was applied at Day 6 (Shelbourne 1975).

At $2 \mathrm{~d}$ after fertilization 40 embryos from each of 8 females were placed singly into glass incubation vials containing $30 \mathrm{ml}$ of $0.45 \mu \mathrm{m}$-filtered, UV-sterilized seawater. These were maintained at $5{ }^{\circ} \mathrm{C}$ and checked daily to record age at hatching and larval age at death due to starvation. On the same day 3 separate groups of 500 embryos from each of 14 females were placed in 42 polyethylene dishes of $400 \mathrm{ml}$ and maintained at $5^{\circ} \mathrm{C}$ for rearing through the larval period. Twice during the $\sim 3$ wk embryonic period, these groups were inspected and dead embryos were removed

At 1 to $3 \mathrm{~d}$ prior to hatching 400 late-eyed embryos from each of the 42 dishes were transferred to submerged platforms in 42 larval rearing aquaria. Larvae were reared in 381 glass aquaria containing 351 of $0.45 \mu \mathrm{m}$-filtered, UV-sterilized seawater. Rearing conditions were static except for partial water replacement $(250 \mathrm{ml})$ at food additions. An antibiotic treatment was applied at 2 wk and light aeration was begun at $4 \mathrm{wk}$ after hatching. Aquaria bottoms were cleaned with siphons every 4 to $5 \mathrm{~d}$. Chilled water baths maintained all aquaria at $7 \pm 0.8^{\circ} \mathrm{C}$ (mean $\pm \mathrm{SD}$ ). Light was provided by two $40 \mathrm{~W}$ fluorescent bulbs suspended 0.75 to $1.5 \mathrm{~m}$ above each aquarium. A $14 \mathrm{~h}$ light $/ 8 \mathrm{~h}$ dark photoperiod was maintained throughout the study. This approximated the natural light regime in the area.

Zooplankton were used as food and were pooled before each feeding. The walls of the aquaria were covered externally with black plastic to enhance prey contrast (Howell 1979). Laboratory-cultured rotifers Brachionus sp. were added to each aquarium every second day from $3 \mathrm{~d}$ after hatching through Week 3 and daily during Weeks 4 and 5 to a calculated final prey density of $4.2 \pm 1.37 \mathrm{ml}^{-1}$. Rotifers were never completely depleted between feedings and were typically 0.25 to $0.5 \times$ the inoculation level when new food was added. From Weeks 6 through 10 the larvae were fed daily with live, field-collected zooplankton (41 to $335 \mu \mathrm{m})$ at a final density of $2.0 \pm 0.83 \mathrm{ml}^{-1}$. The primary constituent of the natural zooplankton were copepod larvae but trochophores were also common. Brine shrimp Artemia sp. (Chinese var.) and rotifers were used as a supplementary food when weather conditions prevented plankton tows or when natural zooplankton were sparse (10 of $30 \mathrm{~d}$ ).

Eggs, larvae, and juveniles were measured with an 
ocular micrometer mounted in a binocular microscope. The yolk diameters of 50 fertilized eggs from each of 14 females were measured within 5 min of fertilization. Sampled larvae and juveniles were anaesthetized in chilled MS-222 (25 $\mathrm{mg} \mathrm{l}^{-1}$ ) prior to measuring their standard or total lengths in $\mathrm{mm}$. The size distribution of hatchlings was established from measurements of 45 larvae $(<24$ h old) from 4 females. Fortnightly samples of larvae, ranging from 10 to 40 per aquarium, were measured first at $2 \mathrm{wk}$ after larvae initiated exogenous feeding and continued through to Week 10. The position of the left (migrating) eye was noted and used to categorize fish into developmental stages of eyes symmetrical, eye migrating, or eye beyond the dorsal crest, at Weeks 8 and 10 . These 3 stages correspond to Stages 3, 4, and 5, respectively, of Shelbourne (1957) and Ryland (1966).

We defined metamorphosis operationally as the point at which the iris of the migrating eye was visible from the right side of the body upon inspection at $6 \times$ magnification. This is equivalent to Stage 5 of Shelbourne (1957) and Ryland (1966) and Stage $H$ of Minami (1981) and Seikai et al. (1986). Beginning at Week 6 , and daily thereafter, aquaria were checked for metamorphosing larvae. Metamorphs, referred to hereafter as juveniles, were measured and their ages recorded. Age at metamorphosis was defined as the number of days between the scoring of a fish as a juvenile and the modal hatching day for larvae from its aquarium. Newly scored juveniles were moved to new aquaria holding only juveniles that had shared an aquarium as larvae, thus maintaining family groups. Juveniles were reared and fed, as above, until terminating the experiment.

To assess the relationship between age at metamorphosis and subsequent growth rates, we assigned juveniles that metamorphosed over a $14 \mathrm{~d}$ interval from 1 of the 42 rearing tanks into $2 \mathrm{~d}$ groups and reared these in 7 separate tanks. These juveniles received the same type and density of zooplankton as larvae and juveniles in all other aquaria. Juveniles from these 7 tanks were measured at metamorphosis, at $10 \mathrm{~d}$ after metamorphosis, and again at a common age since hatching $(10 \mathrm{wk})$, by which time they had been juveniles for 10 to $24 \mathrm{~d}$.

All fish were counted and measured at $10 \mathrm{wk}$ after hatching $(\sim 9.5 \mathrm{wk}$ since first feeding). A subset of the juveniles $(\sim 20 \%)$ was transferred to the Marine Science Research Laboratory, Memorial University, St John's, Nfld, Canada, where they were maintained in 14 full-sibling families at ambient seawater temperatures in a flow-through system through February 1987. These juveniles were housed in $38 \mathrm{l}$ glass aquaria and offered live and frozen Artemia in excess of demand. Lengths were taken on 19 February 1987, at an age of ca 33 wk after hatching. Mean monthly temperatures dropped from 12.7 to $-0.43^{\circ} \mathrm{C}$ from September through February and averaged $4.92^{\circ} \mathrm{C}$.

Analyses. We conducted 3 types of statistical tests on our data. These were tests of (1) equal variation among life history traits, (2) constant growth rates across ages, and (3) no correlations among early life history traits. A minimum of 10 individuals per population was required for inclusion in all tests. The one exception was for tests involving measurements of juveniles at Week 33. There, all observations were used. Standard lengths (SL) were converted to total lengths (TL) before analysis using the relation: $\mathrm{TL}=0.093+1.021 \mathrm{SL}(r=0.99$, $n=75, p<0.001$ ). Computations and tests were performed on SYSTAT (Wilkinson 1986).

Variation in traits. The quantity of variation in early life history traits was compared by tests of no difference in their respective coefficients of variation (CV). The $\mathrm{CV}$ (= SD/mean) standardizes variation for differences in means and, where applicable, units of measure. CVs are dimensionless but their values depend on the measurement used. In this study we evaluated the CV of length as a measure of variation in size. The $\mathrm{CV}$ of length is proportional to the $\mathrm{CV}$ of mass with the proportionality constant equalling the exponent of the equation relating length to mass. Thus, the same ontogenetic pattern of CVs would be detected regardless of whether size is quantified by length or mass. Only the magnitudes of the CVs need be rescaled. The unit of measure of size, when size is compared with traits of unlike units (e.g. age at metamorphosis), must be justified biologically.

We used the bias-correcting formula for small sample sizes proposed by Haldane (1955) to calculate the CVs

$$
\mathrm{CV}^{\cdot}=[1+1 /(4 n)] \cdot \mathrm{CV}
$$

where $n=$ sample size. The test for comparing CVs of any 2 traits (e.g. TL at 2 and 4 wk) was Student's $t$, modified from Sokal \& Braumann (1980) for unequal sample sizes, and calculated as

$$
t=\frac{C V_{1}^{\prime}-C V_{2}^{\prime}}{\mathrm{S}_{C V_{1}^{\prime}}-\mathrm{CV}_{2}^{\prime}}
$$

where

$$
\begin{aligned}
& \mathrm{s}_{\mathrm{CV}}-\mathrm{CV}_{2}^{\prime}=\left\{\left[1+1 /\left(2\left(n_{1}+n_{2}\right)\right)\right]^{2}\left[1 / 2\left(n_{1}+n_{2}\right)\right]\right. \\
& {\left[\mathrm{CV}_{1}^{\prime 2}\left(n_{1} /\left(n_{1}-1\right)+2 \mathrm{CV}_{1}^{\prime 2}\right)+\mathrm{CV}_{2}^{\prime 2}\left(n_{2} /\left(n_{2}-1\right)+2 \mathrm{CV}_{2}^{\prime}{ }^{2}\right)\right.} \\
& \left.\left.\left.-2 \mathrm{CV}_{1}^{\prime} \mathrm{CV}_{2}^{\prime} r\left(\left(n_{1}+n_{2}\right) /\left(n_{1}+n_{2}-2\right)\right) r+2 \mathrm{CV}_{1}^{\prime} \mathrm{CV}_{2}^{\prime}\right)\right]\right\}^{1 / 2}(3)
\end{aligned}
$$

The subscripts reference the 2 traits being compared while $r$ is the population correlation between the 2 traits. The calculated $t$ was tested against a $t$-distribution with $\mathrm{n}_{1}+\mathrm{n}_{2}-2$ degrees of freedom. Using the same test (Eq. 2) we compared the CVs for lengths by developmental stages for the Weeks 8 and 10 samples with $r$ set to zero. 
This test is appropriate when 2 traits potentially covary (Sokal \& Braumann 1980). Note that the calculated $t$ increases as the absolute value of the correlation between the 2 traits increases. Consequently, the probability of $2 \mathrm{CV}$ s being significantly different increases with $r$. In our study individual fish could not be followed for successive samples. For this reason $r$ could not be based on 2 traits from the same individual with the exception of the analysis of length and age at metamorphosis and their derivatives, growth and developmental rate for the entire larval period. To provide a basis for comparing CVs of those traits for which estimates of correlations between traits were not available, we first calculated $t$ under the assumption that $r=0$. We then let $r$ of Eq. (3) range from $-1 \leqslant r \leqslant+1$ at increments of 0.01 and determined the range of $r$ beyond which the $2 \mathrm{CVs}$ differ significantly. There are few published estimates of the correlation between 2 early life history traits in marine fishes based on repeated measures on the same individuals. In the absence of such data the magnitude of this calculated critical value of $r$ serves as a guide to inferences about differences in the intrinsic variation of these traits.

We tested for differences among the CVs for all measured early life history traits (egg size, size and age at hatching, age at starvation, size and age at metamorphosis, and size at fixed ages). Because of the large number (66) of pairwise comparisons of CVs we reduced the rejection criterion to $p<0.05 / 66 \simeq 0.001$ (Miller 1981). Our sample size restriction (minimum of 10 larvae per population) resulted in using data from 18 of our original 42 populations. Eight populations were used in our analysis of the Week 33 data. Data from all populations were pooled prior to comparisons of CVs. Trait distributions from which CVs were compared were unimodal and symmetric, meeting the condition for the test of equality of CVs (Sokal \& Brauman 1980).

The ontogenetic pattern of CVs of lengths-at-ages based on populations was fit by regression models. The CVs were first subjected to a linear model and then tested for nonlinearity by means of a second order polynomial. Subsequently, an asymptotic regression model was used to describe the relation between age and $C V_{s}$ of size of the fish.

Growth rates. The pattern of propagation of variation in size during ontogeny should be influenced by the extent to which growth rate varies with fish age. We estimated and compared age-specific growth rates for this purpose. Growth rate was estimated as average daily length increments for each population. Growth rates were computed from fortnightly length measurements for Weeks 0 to 10 ; from measurements at the beginning and end of the 10 to $24 \mathrm{~d}$ post-metamorphosis interval prior to terminating the constant temperature rearings; and for the period from Weeks 10 to
33 during which juveniles were reared at ambient seawater temperatures.

We assessed ontogenetic changes in growth rates with a 1 -sample profile analysis (Morrison 1976). In this test fortnightly growth rate estimates for a population were treated as a multivariate observation and the null hypothesis of no temporal difference in growth rate was evaluated. Univariate contrasts between growth rate estimates for adjacent sampling intervals were calculated to determine which interval(s) of growth was responsible for rejection of the null hypothesis.

Seventeen populations were used for the profile analysis of growth rates for Weeks 0 to 10 . The analysis of growth profiles for Weeks 0 to 33 was based on 8 of the 15 populations of transferred juveniles. Because of the multiple univariate contrasts between growth rate estimates for the 2 profile analyses 4 and 5 comparisons for profiles on 0 to $10 \mathrm{wk}$ and 0 to $33 \mathrm{wk}$ of growth, respectively), we lowered our rejection criteria to $p<0.05 / 4 \cong 0.012$ and $p<0.05 / 5=0.01$ (Miller 1981). A logarithmic transformation $\left(\log _{e}(Y\right.$ 100)) was applied to the growth rate estimates to equalize their variances.

Correlations among traits. Correlations among the lengths-at-ages, lengths-at-transitions, ages-at-transitions, and growth and developmental rates for the entire larval period were computed from population averages. Correlations among metamorphic characters (length and age at metamorphosis, growth and developmental rate for the larval period) were also calculated from the bivarite response of individuals. Growth rate for the entire larval period was calculated as:

(TL at metamorphosis - average TL of hatchlings). age at metamorphosis

Developmental rate for the entire larval period was computed as:

$$
\text { developmental rate }=(\text { age at metamorphosis })^{-1} .
$$

The sample size restriction ( $\geq 10$ individuals per population) resulted in the number of populations used in the correlation analysis falling from 42 (Week 2) to 18 (Week 10). All 8 populations were used at the Week 33 sample.

\section{RESULTS}

\section{Relative variation in early life history traits}

\section{Variation in sizes}

The CVs of yolk diameters and lengths of hatchlings were small and similar $(4.7 \%$ and $30 \%$, respectively; Table 1) but were significantly different regardless of the degree of correlation between them (Table 2), Variation in length at hatching was significantly less than 
Table 1. Pseudopleuronectes americanus. Statistics for lengths-at-ages and for lengths and ages at life period transitions of winter flounder. Means $(\bar{Y})$, standard deviations (SD), sample sizes ( $n$ ), and coefficients of variation (CV) for larval and juvenile traits are for pooled data from 8 to 18 laboratory populations. Statistics for hatching traits are from individually incubated embryos. All lengths are $\mathrm{mm}$ total length. Ages are in days since first feeding, hatching $(+)$, or fertilization $(++)$. CVs were calculated using Eq. (1)

\begin{tabular}{|lrrrr|}
\hline Trait & $\bar{Y}$ & SD & $n$ & $C V$ \\
\hline $\begin{array}{l}\text { Yolk diameter (mm) } \\
\text { Lengths-at-ages }\end{array}$ & 0.66 & 0.030 & 700 & 0.047 \\
$\quad$ hatching & 3.83 & 0.113 & 45 & 0.030 \\
$\quad 2$ wk & 4.48 & 0.442 & 208 & 0.099 \\
4 wk & 5.39 & 0.725 & 628 & 0.135 \\
$\quad 6$ wk & 6.53 & 0.653 & 351 & 0.100 \\
$\quad 8$ wk & 7.89 & 0.720 & 399 & 0.091 \\
10 wk + & 8.77 & 1.108 & 778 & 0.126 \\
$\quad 33$ wk & 33.07 & 3.050 & 27 & 0.093 \\
Lengths-at-transitions & & & & \\
$\quad$ hatching & 3.83 & 0.113 & 45 & 0.030 \\
$\quad$ metamorphosis & 7.83 & 0.401 & 661 & 0.052 \\
Ages-at-transitions & & & & \\
$\quad$ hatching + + & 20.83 & 0.845 & 250 & 0.041 \\
$\quad$ starvation + & 14.34 & 1.833 & 239 & 0.128 \\
$\quad$ metamorphosis & 59.52 & 7.345 & 662 & 0.123 \\
\hline
\end{tabular}

that for lengths at other ages (Tables 1 and 2; Figs. 1 and 2). The CVs of lengths-at-ages increased from hatching until Week 4 and subsequently stabilized at ca $10 \%$ from Weeks 6 to 33 (Fig. 2). This was a significant departure from linearity for CVs (second order term of polynomial: $F=6.41$, df $=1,197, p<0.01$ ). The parameter estimates $( \pm \mathrm{SE})$ for the best-fitting asymptotic model for population CVs (CV $=a+b \cdot \exp (c \cdot a g e))$, were $0.10( \pm 0.006), \quad-0.08 \quad( \pm 0.013)$, and -0.07 $( \pm 0.028)$ for $a, b$, and $c$, respectively. In this model $a$ estimates the asymptotic value of $\mathrm{CV}$, the $y$-intercept is estimated by $a+b$, and age is measure in days since hatching (Fig. 2). CVs of length-at-ages were greatest at the midpoint of the larval period (Week 4) and at the latter part of the metamorphic interval (Week 10), at which time $82 \%$ of the flounder were juveniles. These intermediate peaks are particularly noticeable on the CVs calculated for pooled data (Table 1; Fig. 2) where the departures are significant (Table 2).

\section{Variation in sizes at transitions}

The CV for length at hatching (3.0\%) was significantly less than that for length at metamorphosis (5.2\%) (Table 2). The variation displayed in lengths at both of these life history transitions was, in turn, significantly smaller than variation in lengths at all other fixed ages throughout the rearing period (Tables 1 and 2). The distribution of lengths of pre-metamorphic, metamorphosing, and postmetamorphic individuals at Weeks 8 and 10 , based on position of the migrating eye, emphasized the restricted variation in lengths during metamorphosis (Fig. 3). The eye-migrating group, which is more broadly defined than our criterion for the metamorphic event, was significantly less variable than the entire distribution and also less than the distributions of pre- or postmetamorphic individuals for Week $8(t=10.27, \mathrm{df}=443, p<0.001$; $t=5.21, \quad \mathrm{df}=213, \quad p<0.001$ and $t=5.17, \mathrm{df}=224$, $p<0.001$, respectively $)$ and Week $10(t=15.53, \mathrm{df}=854$, $p<0.001 ; t=3.31, \quad \mathrm{df}=136, \quad p<0.002$ and $t=6.06$, $\mathrm{df}=670, p<0.001$, respectively).

\section{Variation in ages at transitions}

Age at hatching was significantly less variable than age at starvation and age at metamorphosis. The CVs of age at starvation and age at metamorphosis did not differ significantly (Tables 1 and 2). Age at hatching was significantly more variable than length at hatching ( $\mathrm{CV}=4.1 \%$ and $3.0 \%$, respectively). Age at metamorphosis was significantly more variable than length at metamorphosis (Tables 1 and 2). This indicates that the hatching window and the metamorphosis window are wide in the age dimension relative to the length dimension when winter flounder are reared under constant conditions.

\section{Growth rates}

Growth rate was triphasic during the $33 \mathrm{wk}$ rearing interval (Table 3 ; Fig. 4). Growth rate during the interval from hatching to $2 \mathrm{wk}\left(0.034 \mathrm{~mm} \mathrm{~d}^{-1}\right)$ was significantly lower than during all subsequent intervals. We believe this result to be conservative. Deaths were concentrated in the first $2 \mathrm{wk}$ of larval life and were probably biased towards smaller larvae. This would lead to an overestimate of growth rate for this interval. Growth rates for Weeks 2 to 10 were constant and over double that for the first 2 wk (Table 3; Fig. 4). Growth rate during the juvenile period (Weeks 10 to 33 ) was $0.145 \mathrm{~mm} \mathrm{~d}^{-1}$, again nearly twice that observed during Weeks 2 to 10 (Table 3; Fig. 4).

\section{Correlations among early life history traits}

There were significant, positive, among-population correlations between lengths at adjacent censuses and between length and age at metamorphosis (Table 4). Near metamorphosis (Weeks 8 to 10) the pattern became more complex. Populations of fish with larger than average sizes at Weeks 8 to 10 also had an early 
Table 2. Matrix for comparing equality of coefficients of variation (CVs). The above-diagonal elements are the range of $r$, the correlation coefficient, beyond which the 2 CVs being compared are significantly different. All entries with zeroes denote significant differences regardless of the value of $r$. The below-diagonal elements are the values of $t$, from Eq. (2), under the assumption that $r=0$. All below-diagonal elements are significant at $p<0.001$ except where noted $(\cdot p<0.05$, ns: $p>0.05)$

\begin{tabular}{|c|c|c|c|c|c|c|c|c|c|c|c|c|}
\hline & $\begin{array}{c}\text { Yolk } \\
\text { diameter }\end{array}$ & $\begin{array}{c}\text { Hatch } \\
\text { TL }\end{array}$ & $\begin{array}{c}\text { Wk } 2 \\
\text { TL }\end{array}$ & $\begin{array}{c}\text { Wk } 4 \\
\text { TL }\end{array}$ & $\begin{array}{c}\text { Wk } 6 \\
\text { TL }\end{array}$ & $\begin{array}{c}\text { Wk } 8 \\
\text { TL }\end{array}$ & $\begin{array}{c}\text { WK } 10 \\
\text { TL }\end{array}$ & $\begin{array}{c}\text { Wk } 33 \\
\text { TL }\end{array}$ & $\begin{array}{c}\text { Metam. } \\
\text { TL }\end{array}$ & $\begin{array}{l}\text { Hatch } \\
\text { age }\end{array}$ & $\begin{array}{l}\text { Starv } \\
\text { age }\end{array}$ & $\begin{array}{c}\text { Metam } \\
\text { age }\end{array}$ \\
\hline Yolk & & 0 & 0 & 0 & 0 & 0 & 0 & 0 & $\begin{array}{l}-0.66 \\
+0.66\end{array}$ & $\begin{array}{l}-0.31 \\
+0.31\end{array}$ & 0 & 0 \\
\hline $\begin{array}{l}\text { Hatch } \\
\text { TL }\end{array}$ & 8.88 & & 0 & 0 & 0 & 0 & 0 & 0 & 0 & 0 & 0 & 0 \\
\hline $\begin{array}{c}\text { Week } 2 \\
\text { TL }\end{array}$ & 14.84 & 10.46 & & 0 & $\begin{array}{l}-0.99 \\
+0.99\end{array}$ & $\begin{array}{l}-0.92 \\
+0.90\end{array}$ & 0 & $\begin{array}{l}-0.99 \\
+0.99\end{array}$ & 0 & 0 & 0 & 0 \\
\hline $\begin{array}{c}\text { Week } 4 \\
\text { TL }\end{array}$ & 22.91 & 19.37 & 6.04 & & 0 & 0 & $\begin{array}{l}-0.90 \\
+0.87\end{array}$ & 0 & 0 & 0 & $\begin{array}{l}-0.99 \\
+0.94\end{array}$ & $\begin{array}{l}-0.79 \\
+0.75\end{array}$ \\
\hline $\begin{array}{c}\text { Week } 6 \\
\text { TL }\end{array}$ & 16.22 & 13.24 & $0.17^{\mathrm{ns}}$ & 6.34 & & $\begin{array}{l}-0.86 \\
+0.85\end{array}$ & 0 & $\begin{array}{l}-0.98 \\
+0.96\end{array}$ & 0 & 0 & 0 & 0 \\
\hline $\begin{array}{c}\text { Week } 8 \\
\text { TL }\end{array}$ & 14.93 & 13.37 & $1.39^{\mathrm{n} s}$ & 8.38 & $1.74^{\mathrm{ns}}$ & & 0 & $\begin{array}{l}-0.99 \\
+0.99\end{array}$ & 0 & 0 & 0 & 0 \\
\hline $\begin{array}{c}\text { Week } 10 \\
\text { TL }\end{array}$ & 23.14 & 21.01 & 5.28 & $1.62^{\mathrm{ns}}$ & 5.42 & 7.61 & & 0 & 0 & 0 & $\begin{array}{l}-0.99 \\
+0.99\end{array}$ & $\begin{array}{l}-0.99 \\
+0.99\end{array}$ \\
\hline $\begin{array}{c}\text { Week } 33 \\
\text { TL }\end{array}$ & 12.52 & 5.33 & $0.65^{\mathrm{ns}}$ & 6.34 & $0.96^{\mathrm{ns}}$ & $0.28^{\mathrm{ns}}$ & 5.90 & & 0 & 0 & 0 & 0 \\
\hline $\begin{array}{l}\text { Metam. } \\
\text { TL }\end{array}$ & $2.47^{\circ}$ & 9.59 & 12.51 & 20.43 & 13.68 & 12.37 & 20.61 & 10.11 & & 0 & 0 & 0 \\
\hline $\begin{array}{c}\text { Hatch } \\
\text { age }\end{array}$ & $3.13^{\circ}$ & 3.72 & 11.52 & 19.43 & 13.32 & 12.78 & 20.37 & 8.37 & 3.73 & & 0 & 0 \\
\hline $\begin{array}{l}\text { Starv. } \\
\text { age }\end{array}$ & 18.94 & 12.37 & 3.76 & $0.96^{\mathrm{ns}}$ & 4.16 & 5.84 & $0.33^{\mathrm{ns}}$ & 3.54 & 16.47 & 14.14 & & $\begin{array}{l}-0.99 \\
+0.96\end{array}$ \\
\hline $\begin{array}{l}\text { Metam } \\
\text { age }\end{array}$ & 21.92 & 19.32 & 4.50 & $2.13^{\circ}$ & 4.64 & 6.73 & $0.61^{\mathrm{ns}}$ & 5.05 & 19.39 & 18.94 & $0.80^{\mathrm{ns}}$ & \\
\hline
\end{tabular}

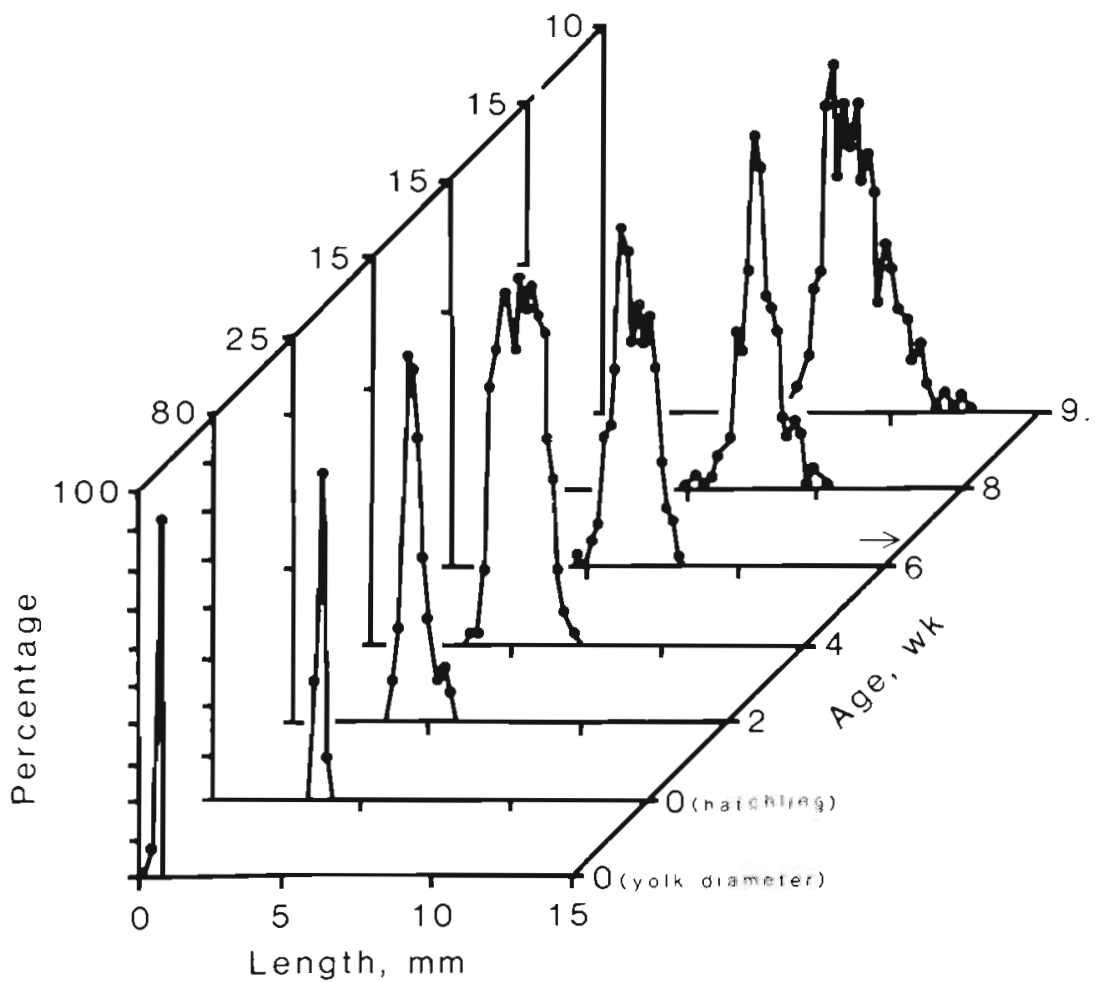

Fi.g. 1. Pseudopleuronectes americanus. Length frequency distributions for individual winter flounder. Yolk diameters, measured immediately after fertilization, were of eggs from 14 females. Hatchlings were from 4 females and were measured within $24 \mathrm{~h}$ of hatching. Distributions of lengths of larvae (ages 2 to $9.5 \mathrm{wk}$ since first feeding) were based on pooled samples from 18 laboratory populations. The first fish scored as a juvenile appeared on Day 40 (arrow) and metamorphosis continued through 9.5 wk. Total length is used for all ages of larvae. The ordinates for each census are adjusted so that the size classes with maximum frequency are of comparable heights. Sample sizes and statistics for these distribution are in Table 1 


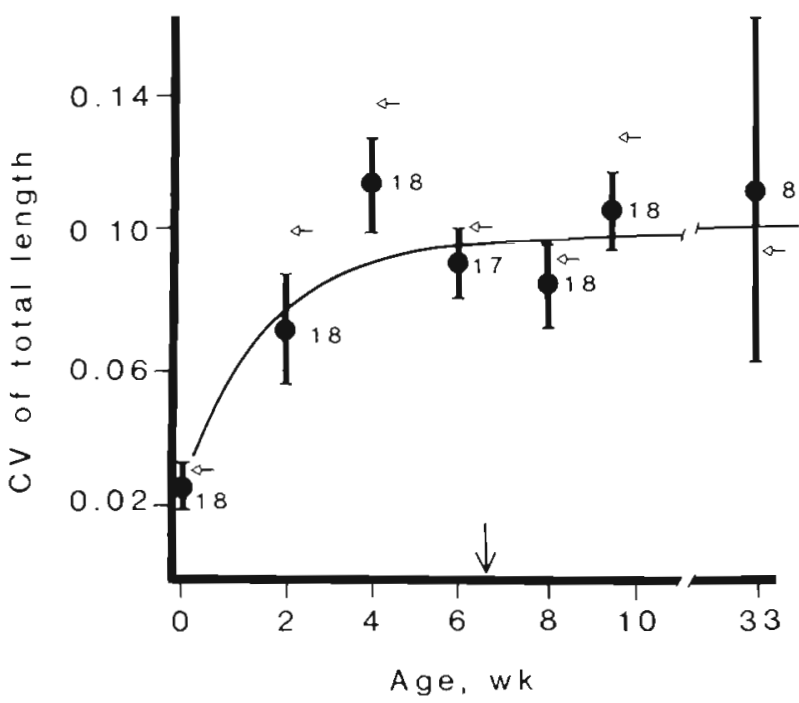

Fig. 2. Pseudopleuronectes americanus. Ontogenetic change in CVs of length-at-age for larval and juvenile winter flounder. Average CVs $\left( \pm 2 \mathrm{SE}_{a} n\right)$ for total length are plotted against ages since first feeding except for Week 0 which was within $24 \mathrm{~h}$ of hatching. The best fitting asymptotic regression, calculated from CVs of populations ( $n$ ), was $\mathrm{CV}=0.100-$ $0.078 \exp (-0.073 \mathrm{age})$, where age is in days since hatching. The locations of CVs calculated from pooled data (Table 1) are identified by the small arrows. The first fish scored as a juvenile occurred on Day 40 (large arrow) and metamorphosis continued through age $9.5 \mathrm{wk}$

average age at metamorphosis. This is indicated by the significant, negative relation between lengths at Weeks 8 and 10 and age at metamorphosis. The positive correlation between length and age at metamorphosis means that fish that metamorphosed earlier were smaller than later-metamorphosing contemporaries. This positive correlation existed among population averages (Table 4 ) and when the bivariate response of individuals was analyzed $(r=0.42, n=661$, $p<0.001$ ). Average growth and developmental rates for the entire larval period were positively, although not significantly related (Table 4). However, when these rates were calculated on all individuals rather than on populations averages, the correlation between them was highly significant $(r=0.68, n=661$, $p<0.001)$. No correlation between larval-metamorphic traits and length at Week 33 was significant. However, the sign of the correlations between lengths at earlier ages and those at Week 33 was consistently positive, and the pattern of correlation between metamorphic traits and lengths at Week 33 suggests a continuation of the relative size structure expressed during the larval and early juvenile periods (Table 4).

Further evidence that larvae with high growth rates retain a size advantage into the early juvenile period is found in the analysis of the population whose juveniles were sorted by age at metamorphosis into $2 \mathrm{~d}$ groups and reared for the first 10 to $24 \mathrm{~d}$ of juvenile life. Length at metamorphosis was independent of age at metamor-

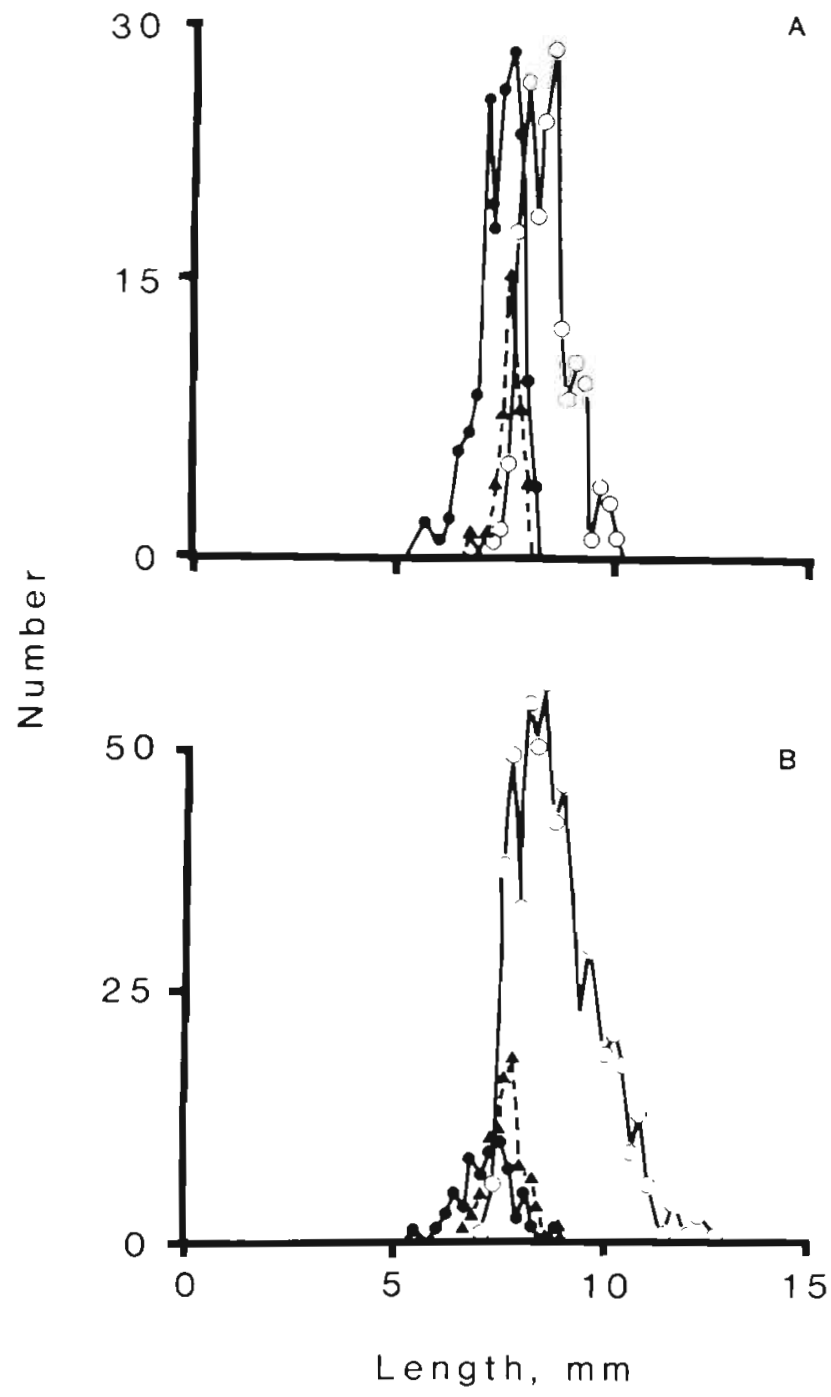

Fig. 3. Pseudopleuronectes americanus. Frequency distributions of total lengths of (A) $8 \mathrm{wk}$ old, and (B) $10 \mathrm{wk}$ old winter flounder classified by the position of their migrating eye. At both censuses the variation in lengths of the metamorphosing individuals ( $\Delta$ ) was less than in the pre-metamorphic $(\bullet$ ) or post-metamorphic (o) groups

phosis in this population (Fig. 5, line a). This population was 1 of 10 of the 18 populations analyzed that did not show a significant, positive within-population correlation between length and age at metamorphosis (Chambers \& Leggett 1987). Larvae that metamorphosed early in this population did, however, have higher growth rates for the entire larval period than larvae that metamorphosed later. Early metamorphs from this population were larger than those that metamorphosed later when compared at a common age since hatching (Fig. 5, line b). This means that the size advantage acquired during the larval period persists into early juvenile life. Larvae that metamorphosed late, on the 
Table 3. Pseudopleuronectes americanus. Analysis of change in growth rates of winter flounder. Profile analyses were conducted on average daily growth rates from Weeks 0 to $10(n=17)$ and from Weeks 0 to $33(n=8)$. In both cases the null hypothesis was: no difference among serially adjacent average growth rates. Abbreviations: $\overline{\mathrm{G}}^{\prime}$, transposed vector of average growth rates; $\overline{\mathrm{G}}_{f}$ average growth rate from Week $i-2$ to $i\left(\bar{G}_{33}\right.$ is growth from Week 10 to 33$)$. The analyses were conducted on loge-transformed data

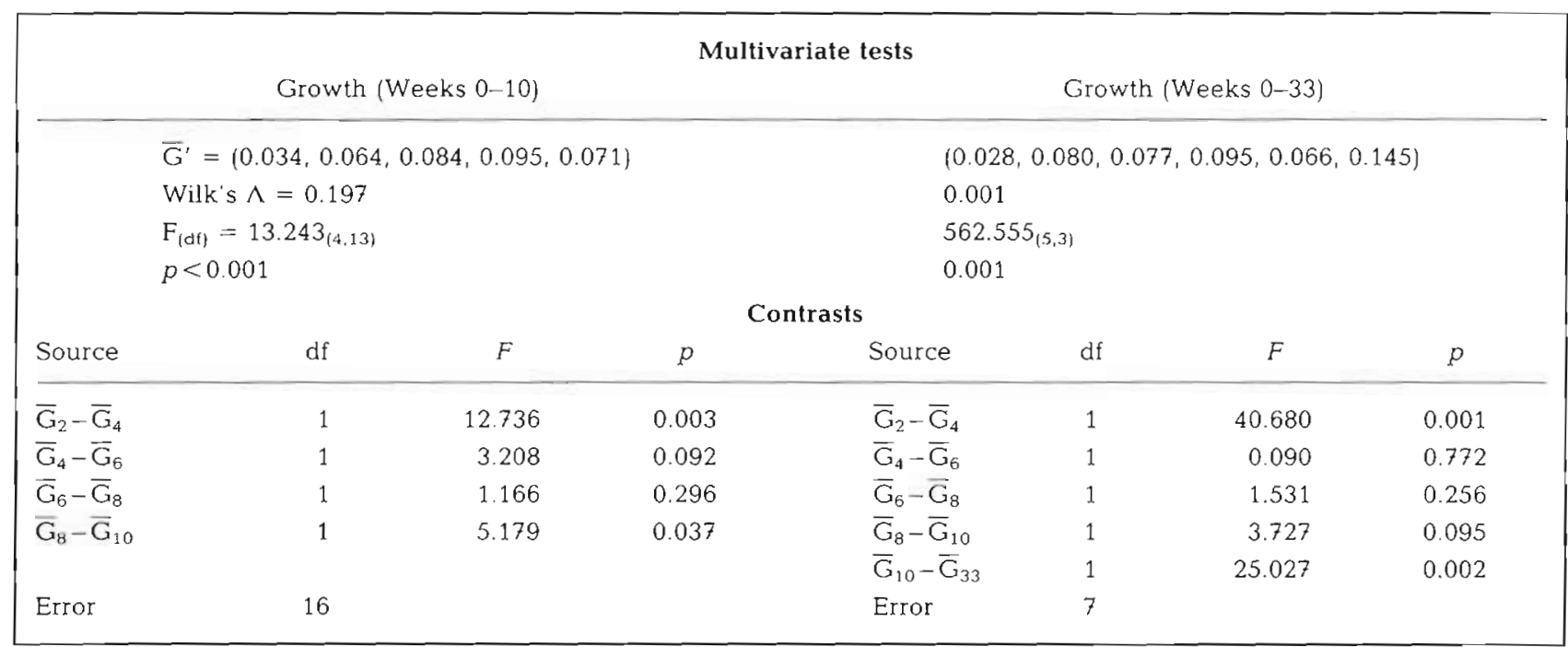

other hand, were smaller at a common age (Fig. 5, line b) yet recouped some, but not all, of the size differential during their first $10 \mathrm{~d}$ after metamorphosis. This is shown by the slope of the relation between length at

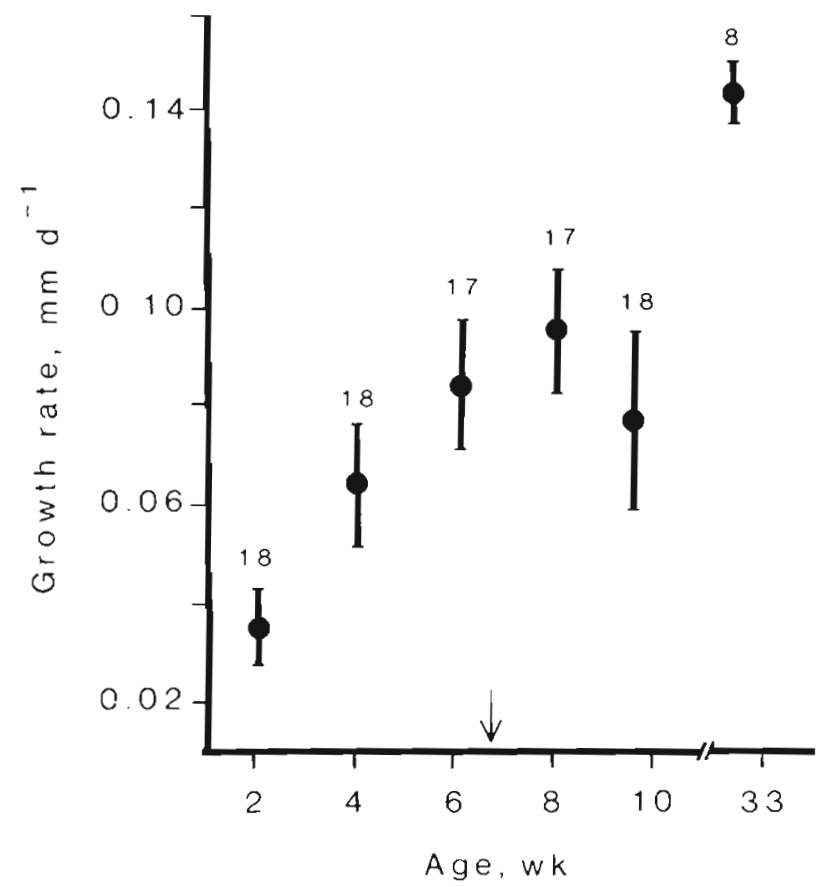

Fig. 4. Pseudopleuronectes americanus. Growth rates for larval and juvenile winter flounder. Average growth rates $1 \pm 2$ $\mathrm{SE}, n)$ are located above the week that terminated the interval. Sample size is the number of populations (aquaria) on which the calculation was based. The first fish scored as a juvenile occurred on Day 40 (arrow) and metamorphosis continued through age $9.5 \mathrm{wk}$
$10 \mathrm{~d}$ after metamorphosis and age at metamorphosis (Fig. 5, line c), which is significantly greater $(F=5.73$, $\mathrm{df}=2,122, p<0.01$ ) than the slope of the relation between length at metamorphosis and age at metamorphosis (Fig. 5 , line a).

\section{DISCUSSION}

\section{Intrinsic variation in early life history traits}

The pattern of variation we observed in early life history traits of winter flounder can be summarized as follows. Variation in length increased rapidly from hatching to a nearly asymptotic value after 2 to $4 \mathrm{wk}$. This level of variation was maintained through Week 33 with the exception of peaks in variation at Week 4 (the approximate midpoint of the larval period) and again at Week 10 (in the latter portion of the metamorphosis interval). Lengths at hatching and metamorphosis displayed low levels of variation with length at hatching less variable than length at metamorphosis. The variation in length at hatching and metamorphosis was less than that expressed in lengths at fixed ages, and less than variation in ages at the respective transitions. Collectively, these 2 patterns indicate that transitions occur at target sizes and that the windows of life period transitions are wider in the age dimension than the length dimension. The level of variation in ages at hatching was low but increased for age at starvation to a level that was equivalent to that expressed in age at metamorphosis. We deal now with the generality and interpretation of this pattern of variation. 
Table 4. Pseudopleuronectes americanus. Correlations among early life history traits in winter flounder. Pearson correlation coefficients are given along with the number of laboratory populations on which the correlation is based Size was measured as total length (TL). Significance levels: ${ }^{\mathrm{a}} p<0.001 ;{ }^{\mathrm{b}} p<0.01 ;{ }^{c} p<0.05 ;{ }^{\mathrm{d}} p<0.10$

\begin{tabular}{|c|c|c|c|c|c|c|c|c|c|c|}
\hline & $\begin{array}{l}\text { Wk2 } \\
\text { TL }\end{array}$ & $\begin{array}{c}\text { Wk } 4 \\
\text { TL }\end{array}$ & $\begin{array}{l}\text { Wk } 6 \\
\text { TL }\end{array}$ & $\begin{array}{l}\text { Wk } 8 \\
\text { TL }\end{array}$ & $\begin{array}{c}\text { Wk } 10 \\
\text { TL }\end{array}$ & $\begin{array}{l}\text { Met. } \\
\text { TL }\end{array}$ & $\begin{array}{l}\text { Growth } \\
\text { rate }\end{array}$ & $\begin{array}{l}\text { Met. } \\
\text { age }\end{array}$ & $\begin{array}{l}\text { Dev. } \\
\text { rate }\end{array}$ & $\begin{array}{c}\text { Wk } 33 \\
\text { TL }\end{array}$ \\
\hline Week 2 & 1 & $\begin{array}{c}0.60^{\circ} \\
32\end{array}$ & $\begin{array}{c}0.38^{d} \\
21\end{array}$ & $\begin{array}{c}-0.10 \\
22\end{array}$ & $\begin{array}{c}-0.23 \\
18\end{array}$ & $\begin{array}{c}-0.36 \\
18\end{array}$ & $\begin{array}{c}-0.58^{c} \\
18\end{array}$ & $\begin{array}{l}0.05 \\
18\end{array}$ & $\begin{array}{c}-0.05 \\
18\end{array}$ & $\begin{array}{c}0.20 \\
8\end{array}$ \\
\hline Week 4 & & 1 & $\begin{array}{c}0.55^{\circ} \\
21\end{array}$ & $\begin{array}{l}0.33 \\
20\end{array}$ & $\begin{array}{l}0.25 \\
18\end{array}$ & $\begin{array}{c}-0.26 \\
18\end{array}$ & $\begin{array}{l}-0.30 \\
18\end{array}$ & $\begin{array}{c}-0.04 \\
18\end{array}$ & $\begin{array}{l}0.02 \\
18\end{array}$ & $\begin{array}{l}0.41 \\
8\end{array}$ \\
\hline Week 6 & & & 1 & $\begin{array}{c}0.55^{c} \\
20\end{array}$ & $\begin{array}{l}0.36 \\
18\end{array}$ & $\begin{array}{c}-0.39 \\
18\end{array}$ & $\begin{array}{c}-0.05 \\
18\end{array}$ & $\begin{array}{c}-0.29 \\
18\end{array}$ & $\begin{array}{l}0.28 \\
18\end{array}$ & $\begin{array}{l}0.06 \\
8\end{array}$ \\
\hline Week 8 & & & & 1 & $\begin{array}{l}0.53^{c} \\
18\end{array}$ & $\begin{array}{c}-0.29 \\
18\end{array}$ & $\begin{array}{l}0.59^{b} \\
18\end{array}$ & $\begin{array}{c}-0.64^{b} \\
18\end{array}$ & $\begin{array}{l}0.62^{\mathrm{b}} \\
18\end{array}$ & $\begin{array}{l}0.42 \\
8\end{array}$ \\
\hline Week 10 & & & & & 1 & $\begin{array}{c}-0.75^{a} \\
18\end{array}$ & $\begin{array}{l}0.24 \\
18\end{array}$ & $\begin{array}{l}0.83^{\circ} \\
18\end{array}$ & $\begin{array}{l}0.82^{\mathrm{a}} \\
18\end{array}$ & $\begin{array}{l}0.31 \\
8\end{array}$ \\
\hline $\begin{array}{l}\text { Length at } \\
\text { metamorphosis }\end{array}$ & & & & & & 1 & $\begin{array}{l}0.19 \\
18\end{array}$ & $\begin{array}{l}0.79^{\mathrm{a}} \\
18\end{array}$ & $\begin{array}{c}-0.80^{\mathrm{a}} \\
18\end{array}$ & $\begin{array}{c}-0.16 \\
8\end{array}$ \\
\hline $\begin{array}{l}\text { Growth rate for } \\
\text { larval period }\end{array}$ & & & & & & & 1 & $\begin{array}{c}-0.45^{\mathrm{d}} \\
18\end{array}$ & $\begin{array}{l}0.43^{\mathrm{d}} \\
18\end{array}$ & $\begin{array}{l}0.18 \\
8\end{array}$ \\
\hline $\begin{array}{l}\text { Age at } \\
\text { metamorphosis }\end{array}$ & & & & & & & & 1 & $\begin{array}{c}-1.00^{\mathrm{a}} \\
18\end{array}$ & $\begin{array}{c}-0.20 \\
8\end{array}$ \\
\hline $\begin{array}{l}\text { Developmental rate } \\
\text { for larval period }\end{array}$ & & & & & & & & & 1 & $\begin{array}{l}0.17 \\
8\end{array}$ \\
\hline
\end{tabular}

\section{Variation in sizes}

Size is the early life history trait for which variances are most frequently reported. A necessary caveat when dealing with these data is that the accuracy and usefulness of the variance estimates depend on the source of data. Studies of fish reared in aquaria or enclosures usually report sizes at fixed ages for fish grown in constant or manipulated environments. This is characteristic of our data. Studies of natural populations typically provide sizes at time of collection but generally lack a temporal resolution below year-class or spawning cohort. A small but growing number of investigators have used the otolith increment technique (Campana \& Neilson 1985) to provide sizes at known ages for natural populations. However, to date these otolith-based studies have employed sample sizes that are too low for reliable tests of trait distributions. For this reason, in this discussion we confine ourselves largely to comparisons of our results with size data drawn from other laboratory studies where the ages of the fish were known.

We calculated the CVs for size-at-age in other laboratory-reared populations of marine fishes and found a pattern of increasing $\mathrm{CV}_{\mathrm{s}}$ after hatching. Some studies report CVs of size to reach a plateau early in larval life (e.g. Beyer \& Laurence 1980, Fukuhara 1983), but in other species the CVs increase through the larval period (Kramer \& Zweifel 1970, Hunter \&
Kimbrell 1980). In this latter group, however, there is evidence that the CVs of lengths-at-ages approach a plateau in the juvenile period (Yamagishi 1969, Purdom 1974, Sakagawa \& Kimura 1976). Beyer \& Laurence (1980) reported a pattern of variation in size with age of laboratory-reared winter flounder similar to ours. They found a doubling of the variation in size from Day 0 to 14 and a stabilization of variation from Day 14 through 42. Regardless of the precise temporal sequence of approach to constant CVs, its presence, by definition, means that the standard deviation of size increases proportionately with the mean of size (or $\sigma^{2} \propto$ $\overline{s i z e}^{2}$ ). If growth rate is constant with age, then the variance of size increases with the square of age as well.

While this within-population temporal pattern of increasing CVs, commonly reaching an asymptotic value early in the life history, seems general, the magnitude of variation at any age may reflect species and environmental differences. Yamagishi (1969) found some evidence that CVs of lengths-at-ages reflect species differences in behavior and life history. Temperature (DeAngelis \& Coutant 1979), crowding (Purdom 1974), and food level (Houde 1977) can also change the magnitude of variances in size during the larval or juvenile periods. However, the reported effect of a given environmental factor on variation is not always consistent in magnitude or even direction among species, including species reared in the same 


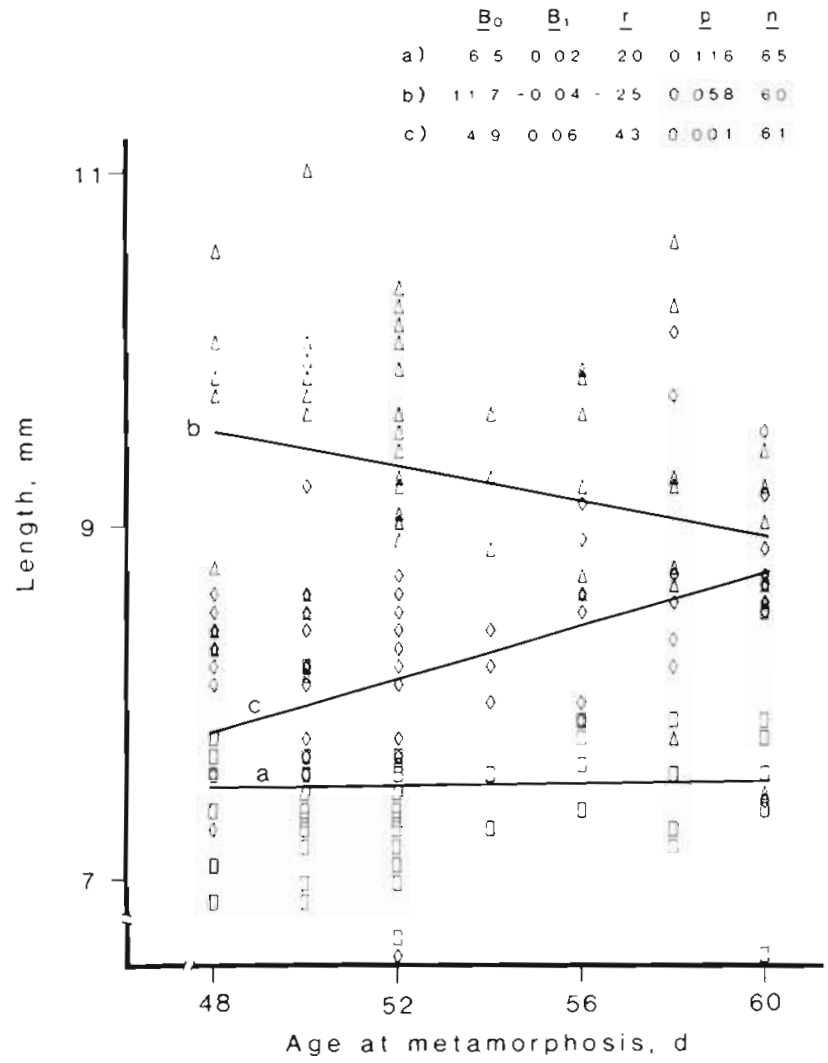

Fig. 5. Pseudopleuronectes americanus. Total lengths of juvenile winter flounder as a function of their age at metamorphosis. Juveniles were assigned to tanks on a $2 \mathrm{~d}$ basis. (a) Lengths at metamorphosis ( $a$ ); (b) lengths at a common age since hatching $(10 \mathrm{wk})$, which ranges from 10 to $24 \mathrm{~d}$ postmetamorphosis ( $\Delta$ ); and (c) lengths at a common juvenile age of $10 \mathrm{~d}$ post-metamorphosis $(\diamond)$. Linear regression parameters: $\mathrm{B}_{0}$, intercept; $\mathrm{B}_{1}$, slope; $r$. Pearson correlation coefficient; $p$, type I probability; $n$, sample size (number of juveniles)

laboratory (e.g. bay anchovy and lined soles: Houde 1977; plaice and sole: Shelboume 1975).

Few studies have followed the distribution of sizes from the larval into the juvenile period while maintaining reasonable sample sizes and replication. Those studies which have tracked growth have generally been motivated by aquacultural objectives, such as assessing the effect of size-grading on production (Purdom et al. 1972, Bowers 1974, Purdom 1974), which obscure patterns of variation. Increases in relative variation in lengths-at-age near or after the metamorphic window have been reported for several laboratoryreared species although the increases were temporary in some cases: Riley (1966) observed a rapid increase in variance during the first $2 \mathrm{wk}$ of the juvenile period in European plaice Pleuronectes platessa; CVs for Japanes sole Zebrias zebra also increased around metamorphosis but subsequently stabilized during the first $2 \mathrm{mo}$ of juvenile life (Yamagishi 1969); CVs for yellowtail flounder Limanda ferruginea rose in samples near metamorphosis, but fell in the single post-metamorphic census (Smigielski 1979); and Seikai et al. (1986) reported a rapid change in the size ranges of Japanese flounder Palalichthys olivaceus during metamorphosis.

We too found an increase in the CV of size at Week 10, which is in the latter portion of the metamorphic window for our populations. This increase in the CVs of lengths-at-ages in the juvenile population is likely a consequence of the increase in growth rate we observed after metamorphosis, coupled with the wide range of ages at metamorphosis (Figs. 2 and 4). The variation we observed in lengths of juveniles at $33 \mathrm{wk}$ did not, however, differ from that seen during the larval period (Tables 1 and 2). The absence of an increase in the CV at 33 wk may have been due to the effect of a reduction in abundances of juveniles during the winter growth period (initial densities of juveniles were 12 to 15 per aquarium; by Week 33 these ranged from 1 to 7 per aquarium). Low initial densities and culling are known to reduce the variation in sizes of fish (Nakamura \& Kasahara 1961, Purdom 1974). The population that we separated into $2 \mathrm{~d}$ groups exhibited a significant degree of growth compensation in the first 2 to $3 \mathrm{wk}$ following metamorphosis (Fig. 5). This may also have led to the lower than expected values of CVs at Week 33.

The variation in lengths of larvae sampled from natural populations may differ from that observed in laboratory populations for several reasons. The mixed ages of larvae in natural populations and the different environmental histories experienced by the larvae should lead to more variation than is expressed by a cohort in the laboratory. Length-at-age data based on estimated ages from daily otolith increments circumvent variance due to different spawning times but do include variance due to the environment. Nonetheless, otolith data reveal little if any increase in variance of fish size with age (Struhsaker \& Uchiyama 1976, Methot \& Kramer 1979, Barkman et al. 1981, Townsend \& Graham 1981, Penney \& Evans 1985, Fives et al. 1986). When scaled to average lengths this suggests that the CVs of size in natural populations may actually decrease with age and size.

The few studies of growth in marine fish larvae that provide growth histories of individuals show length to increase linearly with age. They also show little variation in growth rates among individuals in fieldenclosures (Rosenberg \& Haugen 1982) and natural populations (Penney \& Evans 1985). The reduction of variation in size of fish from natural populations could be due to (1) size-biased mortality (e.g. starvation, predation, cannibalism) against either or both sides of the size distribution or (2) compensatory growth. Sizespecific predation concentrated on smaller larval fish 
has been documented (e.g. Folkvord \& Hunter 1986 Purcell et al. 1987). Size-biased mortality was also noted after the first $12 \mathrm{~d}$ of larval life in enclosurereared turbot in the absence of predators (Rosenberg \& Haugen 1982).

By knowing how the mean and variance of fish sizes change with age, it is possible to predict the quantity of variance in size from estimates of the mean. The direction and magnitude of departures of size distributions of fish from natural or other environments from these predicted distributions can then be used to provide insight into the mechanism of mortality and the nature and magnitude of size selection. Such knowledge also allows the design and prioritization of field studies to ensure that they are consistent with these departures. As noted previously, size-selective predation, biased towards smaller fish, is one obvious mechanism that could reduce variance in sizes as observed in natural populations (e.g. Purcell et al. 1987, van der Veer \& Bergman 1987). Replicated enclosures studies conducted in situ with and without specific mortality agents could add significantly to our understanding of the generation and reduction of variation in sizes of larval and juvenile fish.

As an example of this application we note the results of Laurence et al. (1979) on enclosure-reared larvae of winter flounder. Larvae were reared in the laboratory until $4 \mathrm{wk}$ of age, transferred to an $11.5 \mathrm{~m}^{3}$, predatorfree, in situ enclosure, and sampled 2 wk later. Larvae increased in size and all metamorphosed during this $2 \mathrm{wk}$ interval. We noted, however, a large reduction in the variation of size during this $2 \mathrm{wk}$ interval of rearing (CVs dropped from 0.12 to 0.07 and from 0.53 to 0.31 for length and dry weight, respectively). Laurence et al. did not determine whether deaths during this interval (ca $23 \%$ of 1000 initial larvae) were size-specific.

From their data we reconstructed the expected distribution of lengths and dry weights at termination of their rearing in enclosures in an attempt to identify, or at least eliminate, mechanisms leading to the observed decreases in the CVs. We set the CVs of length and dry weight to constants for the growth interval. This is supported for winter flounder by our data and by rearing data given in Beyer \& Laurence (1980). We assumed normally distributed lengths and log-normally distributed dry weights (again supported by our data and those of Laurence 1979). We found that the variation observed by Laurence et al. at the termination of their experiment was smaller than that to be expected even under strict truncation selection, an extreme and unlikely form of size-specific mortality through which the smallest (or largest) $23 \%$ of the larvae would be systematically removed. We conclude that it is very unlikely that size-specific mortality was solely responsible for the reduction of variation in sizes in their data. Reduced growth of fish after metamorphosis, possibly due to inadequate food for the enclosed juvenile flounder, may have contributed to the reduced CVs.

\section{Variation in sizes at transitions}

We found relatively low levels of variation in lengths at hatching and lengths at metamorphosis, as compared to the variation in lengths at fixed, intermediate ages. The low variation in length at hatching, relative to that seen at subsequent ages, suggests that hatching is more properly viewed as a life cycle transition. Our estimates of variation in length at hatching $(\mathrm{CV}=0.30)$ are consistent with values reported elsewhere for winter flounder and for a variety of other species (Lasker 1964, Yamagishi 1969, Kramer \& Zweifel 1970 Beyer \& Laurence 1981, Fukuhara 1983, 1985, 1987). Variation in size continues to be low through the first week of larval life in many species (Kramer \& Zweifel 1970, Howell 1979, Beyer \& Laurence 1980, Hunter \& Kimbrell 1980, Fukuhara 1983, 1985, Kawamura \& Ishida 1985).

Metamorphosis in winter flounder occurs after a significant period ( 40 to $70 \mathrm{~d}$ ) of growth and development. Variation in length at this life period transition would, therefore, be expected to be greater than at hatching. The variation in length at metamorphosis was indeed greater than that of length at hatching, but was, nonetheless, still relatively low and significantly less than that for lengths at intermediate fixed ages (Tables 1 and 2). Comparison of variation in lengths among winter flounder of a common age, but of different developmental stages, emphasizes this difference (Fig. 3). The restricted variation of lengths at transitions, compared to lengths at fixed ages, implies a target size for these transitions.

\section{Variation in ages at transitions}

The relative variation in age at hatching was significantly less than that for age at starvation or metamorphosis (Table 2). Embryonic development, particularly during the earliest stages, is conservative among taxa (e.g. see Dettlaff 1986) and may account for the low variance in ages (and sizes) at hatching. Ryland (1966) found that developmental timing was canalized through yolk-sac absorption (Ryland's stage 2a) in European plaice, but developmental variation increased markedly during their switch to exogenous feeding. This variation was propagated through the remainder of the larval period. The magnitude of, and correspondence between, CVs of age at starvation and 
age at metamorphosis in our data may reflect the fact that winter flounder pass through a similar point of departure from canalization during early ontogeny.

We found ages at transitions to be more variable than lengths at transitions. This difference was dramatic at metamorphosis (Tables 1 and 2). Our findings of lower variance in length than in age at metamorphosis in winter flounder was mirrored in a survey of intrapopulation results from other marine fishes from laboratory and natural environments (Chambers \& Leggett 1987). Furthermore, age at metamorphosis was more plastic to manipulations of temperature, food level, and crowding than was size at metamorphosis (Chambers \& Leggett 1987).

Both the narrowing of variation in size at metamorphosis vis-à-vis size at fixed ages and the restricted response to environmental change of size versus age at metamorphosis supports the view of target sizes rather than target ages at metamorphosis, regardless of whether size is quantified by length or mass. These results also suggest that life period transitions are critical points in ontogeny.

Because the notions of 'critical period' (May 1974) and 'critical phase' (Gulland 1965) are entrenched in the marine fish literature, a distinction is warranted. We view life period transitions not only as intervals with the potential for excessive mortality (e.g. Wiborg 1976, Larsson 1985), much as the current usage of the term critical period is applied to the time near yolk-sac absorption in manine fish larvae, but also as intervals of high risks of mortality for phenotypic deviates, such as hatchlings or metamorphs of extreme sizes.

\section{Correlations among early life history traits}

Knowledge of the pattern of correlation among early life history traits has 2 potential uses. First, significant correlations among life history traits provide a rationale for using proxy traits to estimate traits whose measurement may be more difficult or costly to obtain. Second, these correlations describe the integration or independence of early life history traits. That 2 traits can vary from being independent to responding as one may seem obvious. This fact is, however, often overlooked in studies of the early life history of marine fishes. For example, in many studies length at metamorphosis is pragmatically defined as attainment of a set size (e.g. Sinclair \& Tremblay 1984, Smith 1985, Bailey \& Stehr 1986, Deegan 1986). Clearly this convention precludes analysis of correlation between size and age at metamorphosis or between growth and developmental rates throughout the entire larval period. In other cases the relationship between 2 traits is less clear for biological reasons. The relationship between growth and development of prefeeding larvae, for example, depends on how size is quantified. If length is used then size and developmental stage are positively related whereas if mass is used the correlation is negative because mass is lost while larvae are dependent on their yolk for nutrition.

Our correlational analysis revealed that populations of larvae having larger average lengths at a given sampling time also had larger larvae at the subsequent sample. As a check that our set of correlations was not simply a manifestation of peculiarities of each rearing tank, we recalculated the correlations between lengths-at-ages based on averages of full-sibling families. Each family average was derived from the averages of 2 or 3 populations. These correlations showed the same serial patterns displayed in Table 4 (i.e. families with large average lengths-at-ages remain relatively large at later ages), thus supporting our among-population analysis. A more powerful test of temporal covariance in size would be possible if serial correlations on individuals were available. Data of this type for turbot larvae, based on otolith increments, also show positive temporal covariance among sizes-atages (Rosenberg \& Haugen 1982).

The pattern of correlations between growth and developmental traits means that fish that metamorphosed early did so at smaller sizes (Table 4). Larvae that metamorphosed early were growing faster than later metamorphosing contemporaries, despite their smaller sizes at metamorphosis. This correlation between growth and developmental rates was significantly $>0$ within 16 of 18 populations (Chambers \& Leggett 1987). Animals that metamorphosed early and at small sizes were larger when compared at a common age. This is revealed in the correlations between metamorphic traits and sizes at Weeks 8 and 10 (Table 4). A similar positive relationship between developmental and growth rates within environments was extracted from data given by Policansky (1982) on laboratory-reared starry flounder Platichthys stellatus, and from Victor's (1986) work on age and size at settlement in natural populations of blueheaded wrasses Thalassoma bifasciatum (Chambers \& Leggett 1987).

Our data on growth of fish during their first 10 to $24 \mathrm{~d}$ after metamorphosis show that size advantages acquired during the larval period were maintained over the first 2 to $3 \mathrm{wk}$ of juvenile life. The correlations between sizes of juveniles at Week 33 and traits of larvae and early juveniles (Week 0 to 10) were in the direction expected from the pattern established during the first $10 \mathrm{wk}$. Collectively, these correlations suggest that size differences expressed during the larval period are perpetuated well into the juvenile period. These differences in sizes in the larval period may, therefore, influence survival in the juvenile period as well. 
There is evidence that growth and survival shortly after metamorphosis in flatfish may depend on the density (Pearcy 1962b, Peterman \& Bradford 1987) and sizes of juveniles (van der Veer \& Bergman 1987). Size selectivity against smaller fish and, it can be argued, intraspecific competition, would both favor fish of larger sizes. At this point in our understanding of the ecology of marine fishes we lack estimates of the benefits and costs of being large-at-age and metamorphosing early as opposed to being large at metamorphosis but experiencing a longer larval period.

Acknowledgements. This work was supported by operating and strategic grants to W.C.L. from the Natural Sciences and Engineering Research Council of Canada and the Subvention Grant Program of the Department of Fisheries and Oceans (DFO), Canada and by a Visiting Scientist Grant to R.C.C. from the Marine Science Research Laboratory, Memorial University of Newfoundland, St John's, Nfld. We are grateful to J. Carscadden and DFO, St John's, Nfld, to the staff of the Huntsman Marine Laboratory, St Andrews, N.B., and to Groupe interuniversitaire de recherche océanographiques du Québec for assistance. We thank N. Shackell, P. Pepin, and 3 anonymous reviewers for comments on an earlier draft. G. Maillet, N. Shackell, K. Tallon, M.-J. Ferreiro, A. Evans, $D$. Horvat, and I. Wenig provided excellent assistance in the field and laboratory.

\section{LITERATURE CITED}

Bailey, K. M., Stehr, C.L. (1986). Laboratory studies on the early life history of the walleye pollock. Theragra chalcogramma (Pallas). J. exp. mar. Biol. Ecol. 99: 233-246

Barkman, R.C., Bengtson, D. A., Beck, A.D. (1981). Daily growth of the juvenile fish (Menidia menidia) in the natural habitat compared with juveniles reared in the laboratory. Rapp. P.-v. Réun. Cons. int. Explor. Mer 178: 324-326

Beyer, J. E., Laurence, G. C. (1980). A stochastic mode of larval fish growth. Ecol. Model. 8: 109-132

Beyer, J. E., Laurence, G. C. (1981). Aspects of stochasticity in modelling growth and survival of clupeoid fish larvae. Rapp. P.-v. Réun. Cons. int. Explor. Mer 178: 17-23

Bowers, A. B. (1974). Marine fish culture in Britain IX. Growth of cultured plaice to marketable size in the laboratory. $\mathrm{J}$ Cons. int. Explor. Mer 35: 149-157

Buckley, L. J. (1982). Effects of temperature on growth and biochemical composition of larval winter flounder Pseudopleuronectes americanus. Mar. Ecol. Prog. Ser. 8: 181-186

Campana, S. E., Neilson, J.D. (1985). Microstructure of fish otoliths. Can. J. Fish. Aquat. Sci. 42: 1014-1032

Cetta, C.M., Capuzzo, J.M. (1982). Physiological and biochemical aspects of embryonic and larval development of the winter flounder Pseudopleuronectes americanus. Mar. Biol. 71: 327-337

Chambers, R.C., Leggett, W. C. (1987). Size and age at metamorphosis in marine fishes: an analyses of laboratoryreared winter flounder (Pseudopleuronectes americanus) with a review of variation in other species. Can. J. Fish. Aquat. Sci 44: 1936-1947

Crawford, R. E., Carey, C. G. (1985). Retention of winter flounder larvae within a Rhode Island salt pond. Estuaries 8: $217-227$
DeAngelis, D. L., Coutant, C. C. (1979). Growth rates and size distributions of first-year smallmouth bass populations: some conclusions from experiments and a model. Trans. Am. Fish. Soc. 108: 137-141

Deegan, L. A. (1986). Changes in body composition and morphology of young-of-the-year gulf menhaden, Brevoria patronus Goode, in Fourleague Bay, Louisiana. J. Fish Biol. 29: $403-415$

Dettlaff, T.A. (1986). The rate of development in poikilothermic animals calculated in astronomical and relative time units. J. therm. Biol. 11: 1-7

Fahay, M.P. (1983). Guide to the early stages of marine fishes occurring in the Western North Atlantic Ocean, Cape Hatteras to the Southern Scotian Shelf. J. NW Atl. Fish. Sci. 4: 1-423

Fives, J.M., Warlen, S. M., Hoss, D.E. (1986). Aging and growth of larval by anchovy Anchoa mitchilli, from the Newport River Estuary, North Carolina. Estuaries 9: 362-367

Folkvord, A., Hunter, J.H. (1986). Size-specific vulnerability of northern anchovy, Engraulis mordax, larvae to predation by fishes. Fish. Bull. U. S. 84: 859-870

Fukuhara, O. (1983). Development and growth of laboratory reared Engraulis japonica (Houttuyn) larvae. J. Fish Biol 23: $641-652$

Fukuhara, O. (1985). Functional morphology and behavior of early life stages of red sea bream. Bull. Jap. Soc. scient. Fish. 51: 731-743

Fukuhara, O. (1987). Larval development and behavior in early life stages of black sea bream reared in the laboratory. Bull. Jap. Soc. scient. Fish. 53: 371-379

Gulland, J.A. (1965). Survival of the youngest stages of fish, and its relation to year-class strength. Int. Comm. NW Atlant. Fish 6: 363-371

Haldane, J. B. S. (1955). The measurement of variation. Evolution 9: 484

Hewitt, R. P., Theilacker, G. H., Lo, N. C. H. (1985). Causes of mortality in young jack mackerel. Mar. Ecol. Prog. Ser. 28: $1-10$

Hjort, J. (1914). Fluctuations in the great fisheries of northern Europe viewed in the light of biological research. Rapp. R.v. Réun. Cons. int. Explor. Mer 20: 1-228

Houde, E. D. (1977). Food concentration and stocking density effects on survival and growth of laboratory-reared larvae of bay anchovy Anchoa mitchilli and lined sole Achirus lineatus. Mar. Biol. 43: 333-341

Howell, B. R. (1979). Experiments on the rearing of larval turbot, Scophthalmus maximus L. Aquaculture 18 : $215-225$

Hunter, J. R. (1981). Feeding ecology and predation of marine fish larvae. In: Lasker, R. (ed.) Marine fish larvae. Washington Sea Grant Program, Seattle, p. 33-77

Hunter, J. R., Kimbrell, C. A. (1980). Early life history of Pacific mackerel, Scomber japonicus. Fish. Bull. U.S. 78: 89-101

Kawamura, G., Ishida, K. (1985). Changes in sense organ morphology and behaviour with growth in the flounder Paralichthys olivaceus. Bull. Japan. Soc. scient. Fish. 51: 155-165

Klein-McPhee, G. (1978). Synopsis of biological data for the winter flounder, Pseudopleuronectes americanus (Walbaum). NOAA Tech. Rep. 414. FAO Fish. Synop. No. 117: $1-43$

Kramer, D., Zweifel, J. R. (1970). Growth of anchovy larvae (Engraulis mordax Girard) in the laboratory as influenced by temperature. Calif. Mar. Res. Comm., CalCOFI Rep. 14: $84-87$

Larsson, P.-O. (1985). Predation on migrating smolt as a reg- 
ulating factor in Baltic salmon, Salmo salar L., populations. J. Fish Biol. 26: 391-397

Lasker, R. (1964). An experimental study of the effect of temperature on the incubation time, development, and growth of Pacific sardine embryos and larvae. Copeia 1964: 399-405

Laurence, G. C. (1975). Laboratory growth and metabolism of the winter flounder Pseudopleuronectes americanus from hatching through metamorphosis at three temperatures. Mar. Biol, 32: 223-229

Laurence, G. C. (1977). A bioenergetic model for the analysis of feeding and survival potential of winter flounder, Pseudopleuronectes americanus, larvae during the period from hatching to metamorphosis. Fish. Bull. U.S. 75: 529-546

Laurence, G. C. (1979). Larval length-weight relations for seven species of Northwest Atlantic fishes reared in the laboratory. Fish. Bull. U. S. 76: 890-895

Laurence, G.C., Halavik, T. A., Burns, B. R., Smigielski, A. S. (1979). An environmental chamber for monitoring in Situ' growth and survival of larval fishes. Trans. Am. Fish. Soc. 108: $197-203$

Leggett, W. C. (1986). The dependence of fish larval survival on food and predator densities. In: Skreslet, S. (ed.) The role of freshwater outfiow in coastal marine ecosystems. Springer-Verlag, Berlin, p. 117-137

May, R. C. (1974). Larval mortality in marine fishes and the critical period concept. In: Blaxter, J.H.S. (ed.) The early life history of fish. Springer-Verlag, Berlin, p. 3-19

McGurk, M. D. (1986). Natural mortality of marine pelagic fish eggs and larvae: role of spatial patchiness. Mar. Ecol. Prog. Ser. 34: 227-242

Methot, R. D., Kramer, D. (1979). Growth of northern anchovy, Engraulis mordax, larvae in the sea. Fish. Bull. U.S. 77 : $413-423$

Miller, R. G. (1981). Simultaneous statistical inference. Springer-Verlag, New York

Minami, T (1981). The early life history of a flounder Pseudorhombus pentophthalmus. Bull. Jap. Soc scient. Fish. 47: 849-856

Morrison, D.F. (1976). Multivariate statistical methods. McGraw-Hill, New York

Murphy, G.I. (1961). Oceanography and variations in the Pacific sardine population. Calif. Mar. Res. Comm., CALCOFI Rep. 8: 55-64

Nakamura, N., Kasahara, S. (1961). A study on the phenomenon of the tobe-koi or shoot carp - IV Effects of adding a small number of larger individuals to the experimental batches of carp fry and of culture density upon the occurrence of shoot carp. Bull. Jap. Soc. scient. Fish. 27: 958-962

Pearcy, W. G. (1962a). Ecology of an estuarine population of winter flounder Pseudopleuronectes americanus (Walbaum). II. Distribution and dynamics of larvae. Bull. Bingham oceanogr Coll. 18: 16-38

Pearcy. W. G. (1962b). Ecology of an estuarine population of winter flounder Pseudopleuronectes americanus (Walbaum). III. Distribution, abundance, growth, and production of juveniles; survival of larvae and juveriles. Bull. Bingham oceanogr Coll. 18: 39-64

Pearcy, W. G. (1962c). Ecology of an estuarine population of winter flounder Pseudopleuronectes americanus (Walbaum). IV Food habits of larvae and juveniles. Bull. Bingham oceanogr. Coll. 18: 65-78

Penney, R. W., Evans, G. T (1985). Growth histories of larval redfish (Sebastes spp.) on an offshore Atlantic fishing bank determined by otolith increment analysis. Can. J. Fish. Aquat. Sci. 42: 1452-1464
Peterman, R.M., Bradford, M. J. (1987). Density-dependent growth of age 1 English sole (Parophrys vetulus) in Oregon and Washington coastal waters. Can. J. Fish. Aquat. Sci. 44. $48-53$

Policansky, D. (1982). Influence of age, size, and temperature on metamorphosis in the starry flounder, Platichthys stellatus. Can. J. Fish. Aquat. Sci. 39: 514-517

Purcell, J. E., Siferd, T. D., Marliave, J. B. (1987). Vulnerability of larval herring (Cluepa herengus pallasi) to capture by the jellyfish Aequorea victoria. Mar. Biol. 94: $157-162$

Purdom, C.E. (1974). Variation in fish. In: Harden Jones, F. R. (ed.) Sea fisheries research. Elek Science, London p. $347-355$

Purdom, C.E., Jones, A., Lincoln, R. F. (1972). Cultivation trials with turbot (Scophtalmus maximus). Aquaculture 1. $213-230$

Riley, J.D. (1966). Marine fish culture in Britain. VII Plaice (Pleuronectes platessa L.) post-larval feeding on Artemia salina L. nauplii and the effects of varying feeding levels. J. Cons. perm. int. Explor. Mer 30: 204-221

Rogers, C. A. (1976). Effects of temperature and salinity on the survival of winter flounder embryos. Fish. Bull. U.S. 74: $52-58$

Rosenberg, A. A., Haugen, A. S. (1982). Individual growth and size-selective mortality of larval turbot (Scophthalmus maximus) reared in enclosures. Mar. Biol. 72: 73-77

Ryland, J.S. (1966). Observations on the development of larvae of the plaice, Pleuronectes platessa L in aquaria. J. Cons perm. int. Explor Mer 30: 177-195

Sakagawa, G. T., Kimura, M. (1976). Growth of laboratoryreared northern anchovy, Engraulis mordax, from southern California. Fish. Bull. U. S. 74: 271-279

Seikai, T., Tanangonan, J. B., Tanaka, M. (1986). Temperature influence on larval growth and metamorphosis of the Japanese flounder Palalichthys olivaceus in the laboratory. Bull. Jap. Soc. scient. Fish. 52: 977-982

Shelbourne, J. E. (1957). The feeding and condition of plaice larvae in good and bad plankton patches. J. mar. biol. Ass. U. K. $36: 539-552$

Shelbourne, J. E. (1975). Marine fish cultivation: pioneering studies on the culture of the larvae of the plaice (Pleuronectes platessa L) and the sole (Solea solea L.). Fish. Invest., Ser. II. 27: 1-29

Sinclair, M., Tremblay, M. J. (1984). Timing of spawning of Atlantic herring (Clupea harengus harengus) populations and the match-mismatch theory. Can. J. Fish. Aquat. Sci. 4.: 1055-1065

Smigielski, A. S. (1979). Induced spawning and larval rearing of the yellowtail flounder, Limanda ferruginea. Fish. Bull. U.S. 76: 931-936

Smith, P. E. (1985). Year-class strength and survival of 0-group clupeoids. Can. J. Fish. Aquat. Sci. 42 (Suppl. 1): 69-82

Sokal, R. R., Braumann, C.A. (1980). Significance tests for coefficients of variation and variability profiles. Syst. Zool. 29: $50-66$

Struhsaker, P., Uchiyama, J.H. (1976). Age and growth of the nehu, Stolephorus purpureus (Pisces: Engraulidae), from the Hawaiian Islands as indicated by daily growth increments of sagittae. Fish. Bull. U. S. 74: 9-17

Townsend, D.W., Graham, J. J. (1981). Growth and age structure of larval Atlantic herring, Clupea harengus harengus, in the Sheepscot River Estuary, Maine, as determined by daily growth increments in otoliths. Fish. Bull. U. S. 79 $123-130$

Veer, H.W., van der, Bergman, M. J. N. (1987). Predation by crustaceans on a newly settled 0-group plaice Pleuronec- 
tes platessa population in the western Wadden Sea. Mar Ecol. Prog. Ser. 35: 203-215

Victor, B. C. (1986). Delayed metamorphosis with reduced larval growth in a coral reef fish (Thalassoma bifasciatum). Can. J. Fish. Aquat. Sci. 43: 1208-1213

Ware, D.M. (1975). Relation between egg size, growth, and natural mortality of larval fish. J. Fish. Res. Bd Can. 32: 2503-2512

Wiborg, K. F. (1976). Larval mortality in marine fishes and the critical period concept. J. Cons. int. Explor. Mer 37: 111
Wilkinson, L. (1986). SYSTAT: the system for statistics. SYSTAT, Inc. Evanston

Williams, G.C. (1975). Viable embryogenesis of the winter flounder Pseudopleuronectes americanus from -1.8 to $15^{\circ} \mathrm{C}$. Mar Biol. 33: 71-74

Yamagishi, H. (1969). Postembryonal growth and its variability of the three marine fishes with special reference to the mechanism of growth variation in fishes. Res. Pop. Ecol. 11: $14-33$

This article was presented by Dr K. Sherman; it was accepted for printing on May 20, 1988 